\title{
Robert J. Genco: A Legacy of Lifelong Innovation and Inspiration
}

\author{
Caroline Genco $^{1} \cdot$ Denis Kinane ${ }^{2}$
}

Published online: 15 January 2020

(C) The Author(s) 2020

We are both honored to be afforded the opportunity to co-edit this commemorative edition of the journal in honor of our dear colleague, friend, and mentor Dr. Robert Joseph Genco. Dr. Robert Genco, Ph.D., died on March 6, 2019, at the age of 80, leaving behind an enormous legacy of excellence in research, teaching, mentoring, and leadership. He was a role model on multiple levels for so many of us who had the pleasure to know him, to work with him, and to consider him our friend.

Dr. Genco graduated with a D.D.S. from the University at Buffalo School of Dental Medicine in 1963 and earned his Ph.D. in Microbiology and Immunology from the University of Pennsylvania in 1967. He subsequently returned to his native city of Buffalo, NY. He spent the majority of his life there, building an extraordinary scientific career while making ample time for family as a devoted father, grandfather, and great-grandfather.

Many will consider his work on diabetes and how oral health affects systemic health to be his most groundbreaking legacy, but our inspirations from Bob are from his seminal papers on host-pathogen interactions in the context of periodontal disease. Dr. Genco and his colleagues were among the first to report that gum disease is connected to heart disease and stroke. His recent studies included examining the link between periodontitis and other chronic diseases such as obesity, as well as searching for clues about how pregnant women's oral health may affect the health of their offspring. Many of Dr. Genco's seminal papers are referred to in this commemorative issue of Current Oral Health Reports.

This article is part of the Topical Collection on Host Parasite Interactions in Periodontal Disease

Caroline Genco

caroline.genco@tufts.edu

1 Department of Immunology Tufts University School of Medicine, Boston, MA, USA

2 University of Pennsylvania School of Dental Medicine, Philadelphia, PA, USA
Dr. Genco's numerous awards included the ADA's Gold Medal for Excellence in Dental Research in 1991 and Norton M. Ross Award for Excellence in Clinical Research in 2003. While accepting the 1991 gold medal, Dr. Genco said, "I am proud of the research that drives the dental profession. We face serious challenges in the dental profession and science is the answer." Bob embodied this statement in a multitude of forms: he was so passionate and so impressed and appreciative of the excellence in oral research that was going on all around him and to which he had contributed immensely. His interest, enthusiasm, and his critique of his colleagues' work were incisive and always constructive, offering different viewpoints to consider.

Dr. Genco served as editor in chief of the Journal of Periodontology and Annals of Periodontology from 1988 to 2006 and in his career published more than 395 scientific papers which deservedly hold an overall outstandingly high-impact factor. As editor of the Journal of Periodontology, at the International Association for Dental Research Meeting (IADR), and in many workshops, he adroitly argued his invariably correct point and was always a gentleman. Bob always saw the bigger picture. In 2016, Dr. Genco's tenure at Penn was re-celebrated, and he was named a distinguished alumnus. As dean of the School of Dental Medicine at the time, Denis was personally appreciative of the fine words that Bob had to say about the University of Pennsylvania.

We will always cherish his evenhanded, unbiased approach to hypotheses, his ability to see both sides of an argument, and his recognition of the importance of both host response and microbial biofilm as critical to the disease process. Bob was, as usual, right on the money, and his appreciation of the intricate host-pathogen interactions was educational for all of us. His most recent position was as director of the Microbiome Center at the University at Buffalo School of Dental Medicine, which conducts research on the microorganisms living in and on the human body. This recent work is also discussed in this current commemorative volume. 
Many will know his list of incredible, highly accomplished trainees even better than we do. For example, Marty Taubman recently authored an excellent discovery article on Bob's Ph.D. students that reads like a Periodontology Hall of Fame! Bob was a driving force in Caroline's career dating back to 1976 and was a lifelong mentor to her on so very many levels. Denis's first discussions with Bob were at the IADR Meeting in Glasgow in 1992, where he was instantly struck by Bob's enthusiasm, kindness and eagerness to mentor, and inspirational nature.

Dr. Genco served as vice provost of the UB Office of Science, Technology Transfer and Economic Outreach (2002-2016). In this role, he successfully commercialized his own discoveries and those of other UB faculty and students. It is not surprising then that in December of 2019, Dr. Genco was posthumously named a fellow of the National Academy of Inventors, a well-deserved award for a man who saw no limits to where science can take us.

We miss Bob's larger-than-life smile, his love for science, and most importantly his love for life. We know that many of you feel $>$ the same way. When we reached out to Bob's colleagues and mentees for assistance in putting together this commemorative volume, we were amazed at how quickly we received $100 \%$ participation. We are thankful to the authors of all the chapters for their participation in this special issue. Most importantly, we are forever grateful to Bob Genco for his wisdom, his grace, and his enduring friendship throughout the years.

Caroline Attardo Genco and Denis Kinane

Open Access This article is licensed under a Creative Commons Attribution 4.0 International License, which permits use, sharing, adaptation, distribution and reproduction in any medium or format, as long as you give appropriate credit to the original author(s) and the source, provide a link to the Creative Commons licence, and indicate if changes were made. The images or other third party material in this article are included in the article's Creative Commons licence, unless indicated otherwise in a credit line to the material. If material is not included in the article's Creative Commons licence and your intended use is not permitted by statutory regulation or exceeds the permitted use, you will need to obtain permission directly from the copyright holder. To view a copy of this licence, visit http://creativecommons.org/licenses/by/4.0/. 